\title{
MONITORING OF SEASONAL VARIATION OF SOME TRACE METALS CONCENTRATION IN SURFACE WATER COLLECTED FROM THE COASTAL AREA OF BANGLADESH
}

\author{
Raknuzzaman, M., M. H. Al-Mamun, M. K. Ahmed ${ }^{1}$, M. Tokumura ${ }^{2}$ and S. Masunaga ${ }^{3}$ \\ Department of Fisheries, University of Dhaka, Dhaka 1000, Bangladesh; ' Department of \\ Oceanography, University of Dhaka, Dhaka 1000, Bangladesh; ${ }^{2}$ Graduate School of Nutritional and \\ Environmental Sciences, University of Shizuoka, Japan; ${ }^{3}$ Graduate School of Environment and \\ Information Sciences, Yokohama National University, Japan
}

\begin{abstract}
This study was conducted to determine the seasonal variation of $\mathrm{Cr}, \mathrm{Ni}, \mathrm{Cu}, \mathrm{Zn}, \mathrm{As}, \mathrm{Cd}$ and $\mathrm{Pb}$ concentrations in water from four coastal sites of Bangladesh. The mean concentrations of trace metals in the water samples in the range of each elements were $\mathrm{Cr}$ (2.6-15.3), $\mathrm{Ni}(5.1-77.5), \mathrm{Cu}(10.2-510), \mathrm{Zn}(5.0-1390)$, As (2.1-13.3), $\mathrm{Cd}(0.006-0.09), \mathrm{Pb}(0.4-109 \mu \mathrm{g} / \mathrm{l})$ in summer and $\mathrm{Cr}(3.6-43.7), \mathrm{Ni}(10.8-42.4), \mathrm{Cu}$ (7.3-45.2), $\mathrm{Zn}$ (18.0-73.9), As (4.0-19.7), $\mathrm{Cd}(0.025-0.087), \mathrm{Pb}(2.8-34.8 \mu \mathrm{g} / \mathrm{l})$ in winter. The mean concentrations of the metals in water followed a decreasing order of $\mathrm{Zn}>\mathrm{Cu}>\mathrm{Pb}>\mathrm{Ni}>\mathrm{Cr}>\mathrm{As}>\mathrm{Cd}$ in the summer and $\mathrm{Zn}>\mathrm{Ni}>\mathrm{Cr}>\mathrm{Cu}>\mathrm{Pb}>\mathrm{As}>\mathrm{Cd}$ in the winter. The water of Cox's Bazar hatchery site showed the highest levels of $\mathrm{Zn}$ (1390), $\mathrm{Cu}(510)$ and $\mathrm{Pb}(109 \mu \mathrm{g} / \mathrm{l})$ in summer while As (19.7 $\mu \mathrm{g} / \mathrm{l})$ showed highest in Cox's Bazar Bakkhali estuary in the winter samples. The elevated level of Ni $(77.5 \mu \mathrm{g} / \mathrm{L})$ in the summer and $\mathrm{Cr}$ $(43.7 \mu \mathrm{g} / \mathrm{l})$ in the winter water samples were also found in the Sundarbans site. The mean concentrations of all estimated trace metals were higher in the winter than in the summer season. It was both in the Chittagong port and Meghna estuary. For the Meghna estuary, the highest concentration of $\mathrm{Zn}(36.0 \mu \mathrm{g} / \mathrm{l})$ was observed in the water sample of winter season. Some trace metals exceeded the international quality guidelines. Suspended solid, temperature, rainfall, anthropogenic inputs and geomorphologic setup are influenced by seasonal vagaries which alter the variation of metal distribution.
\end{abstract}

Key words: Bangladesh, coastal pollution, trace metals, water, sunderbans, Cox’s bazar.

\section{INTRODUCTION}

Over the last few decades, trace metal contamination has been identified as a great concern in coastal aquatic environment. The accumulation of trace metals in the coastal environment especially in water ecosystem has become a vital problem throughout the world (Gupta et al. 2009, Wang et al. 2010). Trace metals discharged into the marine environment and damage marine species diversity as well as ecosystems. This happens due to their toxicity, long persistence, bio-accumulation and biomagnification in the food chain (Eisler 1988, Rahman and Islam 2010, Ebrahimpour et al. 2011). Substantial unplanned development in the industrialization, huge urbanization, population growth, agricultural expansion, transboundary political issues and different anthropogenic activities accelerate the trace metals inclusion into the estuarine and coastal environment (Tarras-Wahlberg et al. 2001, Jordao et al. 2002).

However, accumulation of trace metals in surface water in aquatic environment might be toxic to water-dwelling organisms and fishes (Praveena et al. 2007). Fishes are often at the top of the aquatic food chain which may accumulate large amounts of some metals from the water and sediment (Mansour et al. 2002). The consumption of fishes has been increased considerably due to their contribution in the field of sophisticated protein, low saturated fat and omega fatty acids supply potentials (Copat et al. 2012). Trace metals contaminated water has become an important worldwide issue not only threat to fish, but also menace to human health and the health of other fish consuming animals. 
Bangladesh is a low-lying country having large marshy jungle coastline of $580 \mathrm{~km}$ on the northern littoral of the Bay of Bengal. It is one of the largest deltas in the world. This is formed mainly by the Ganges (Padma)-Brahmaputra-Meghna (GBM) river system, except for the hilly regions in the northeast and southeast and terrace land in northwest and central zones. A network of 230 rivers with their tributaries and distributaries crisscross the country and, therefore, the country is virtually a conglomerate of islands. The river Ganges and Yamuna have been one of the major recipients of industrial effluents from neighboring country, like India, entering into Bangladesh as the Padma and the Jamuna. The river Padma and the Jamuna are joined together in Chadpur forming the Meghna river which dumping up sediments to the water with unknown quantities of poisonous residues from agricultural, chemical, industrial, farm effluents, solid waste, sewage disposal through Meghna estuary, Bhola into the coastal water. The coming waste materials pollute the coastal aquatic environment that contaminate fishes, crustaceans and other aquatic biota. But these trace metals contamination has been paid less attention by the concerned authorities.

In Bangladesh, factors such as salinity, total organic carbon (TOC), suspended solid (SS), tide, temperature, rainfall, terrestrial runoff, anthropogenic inputs and above all geomorphological setup are influenced by seasonal vagaries which might have played a vital role in the variation of metal distribution in this tropical estuarine system (Ali and Abdel Satar 2005). Considering the variation of the physico-chemical properties and geomorphologic setup in relation to seasons, the reasonable and adequate ground was formulated to estimate the seasonal fluctuation and distribution of the trace metals contamination in water that was collected from Bangladeshi coastal zone. Very few studies on the monitoring of trace metals have been conducted, but no detail studies have been carried out in the areas yet. It is high time to envisage our views to the problem with integrated approaches.

\section{MATERIAL AND METHODS}

The Himchari National Park is located (21 $35^{\prime}$ to $21^{\circ} 44^{\prime} \mathrm{N}$ and $91^{\circ} 98^{\prime}$ to $\left.92^{\circ} 05^{\prime} \mathrm{E}\right)$ on the outskirts of Cox's Bazar city extending from Lighthouse para on the north to Rejhukhal on the south with an expansion of around $17 \mathrm{~km}^{2}$. It consists of three unions, namely South Mithachari, Jhilongja and Khuniapalong. In exercise of the power conferred by the section 23(II) of Bangladesh Wildlife Preservation Act 1974 the Government of the People's Republic of Bangladesh proclaimed the park measuring about 1729 ha $(4,271.15$ acres $)$ to be a National Park on the $15^{\text {th }}$ February 1980. It was proclaimed as National Park under three forest block named Bhangamura Reserve Forest (872 ha), part of Chainda Reserve Forest (62 ha), and part of Jhilongja Protected Forest ( $795 \mathrm{ha}$ ). These three blocks at present cover four forest beats, namely Kolatoli, Chainda, Jhilongja and Link Road. The total landscape area of the Protected Forest (PF) is about 10,849 ha of which 1,729 ha core zone, 5,247 ha buffer zone and 3,873 ha private land. It is under the jurisdiction of Cox's Bazar South Forest Division within Cox's Bazar district (Fig. 1).

Four sampling sites (viz. Cox's Bazar, Chittagong, Meghna Estuary in Bhola, and the Sundarbans) with three different locations of each of the sites were investigated in the southeast and southwest coastal area of Bangladesh (Fig.1). The first site (St. 1) was located at the southeast coastal area in Cox's Bazaar (latitudes $21^{\circ} 27^{\prime} 02^{\prime \prime} \mathrm{N}$ to $21^{\circ} 26^{\prime} 33^{\prime \prime} \mathrm{N}$ and longitudes $91^{\circ} 58^{\prime} 16^{\prime \prime} \mathrm{E}$ to $91^{\circ} 57^{\prime} 0^{\prime \prime} \mathrm{E}$ ). Cox's Bazar is a seaside tourist town, having two diverse ecological sub sites like Bakkhali estuary and hatchery sites. The Bakkhali estuary is an important economic part within the Coax's Bazar district having a harbor and imperative local fishery of coastal ecosystem types. The estuary is about $0.5 \mathrm{~km}$ wide and $>10 \mathrm{~m}$ deep at its mid-point. It is influenced by semi-diurnal tides. The estuarine zone is characterized by the long intertidal mudflat. Moreover, Moheshkhali Island is one of the important economic zones incorporating to Bakkhali estuary through (9 to 11 kilometer long) Maheshkhali channel to Cox's Bazaar Central 
Island. Likewise, hatchery site was very close (200-300 m) to the sea beach along with sampling sites (where more than 53 shrimp hatcheries and aquafarms) big fish landing centers, huge hotels for amusements and some industries were located. Coastal shrimp culture has been widely practiced in this coastal area during a couple of decades. These sampling areas were seriously influenced by the chemical effluents and wastage from the unplanned industries.

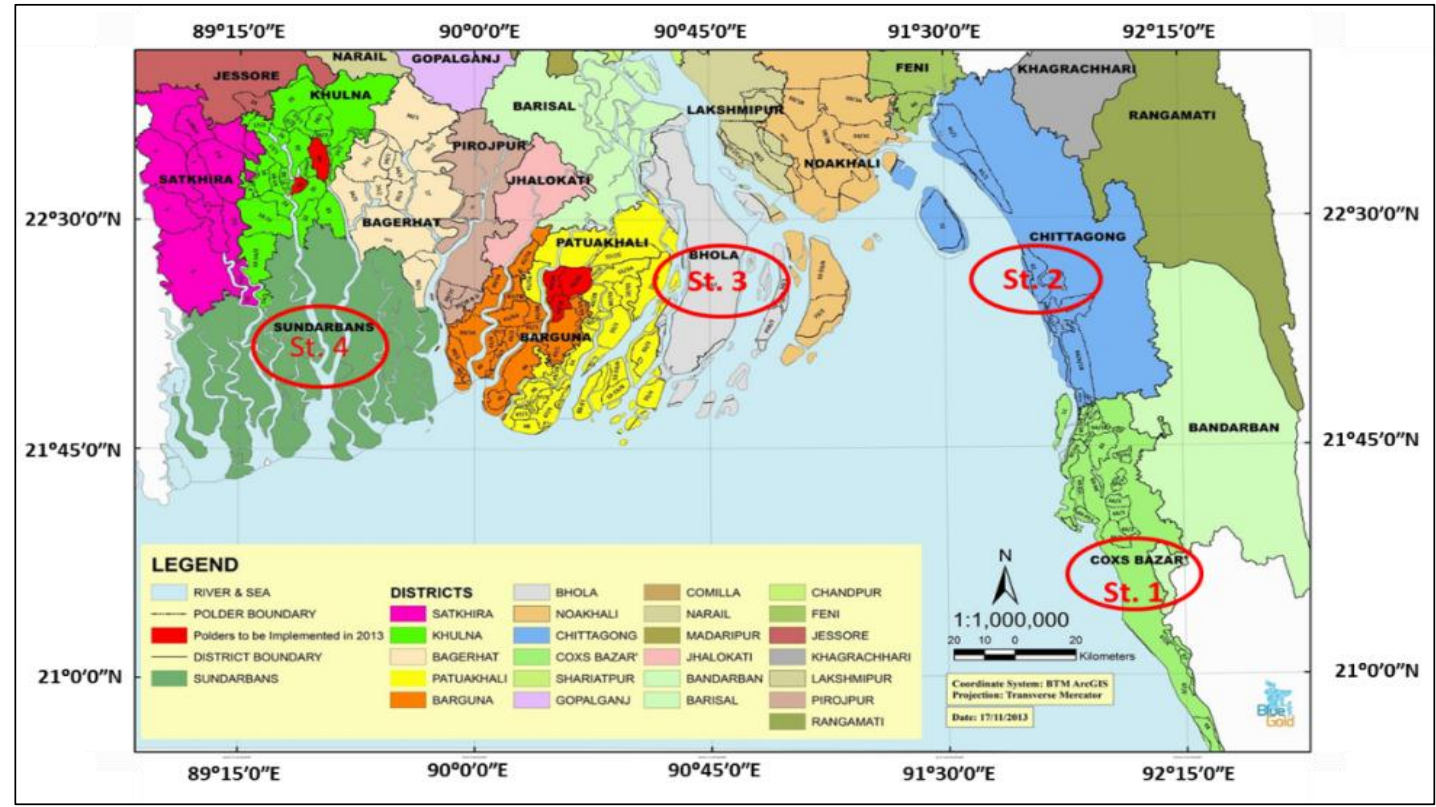

Fig. 1. Map showing sampling sites in the coastal area of Bangladesh.

The second site (St. 2) was located near the Chittagong port and ship breaking area (latitudes $22^{\circ} 13^{\prime} 27^{\prime \prime} \mathrm{N}$ to $22^{\circ} 38^{\prime} 22^{\prime \prime} \mathrm{N}$ and longitudes $91^{\circ} 48^{\prime} 14^{\prime \prime} \mathrm{E}$ to $91^{\circ} 32^{\prime} 45^{\prime \prime} \mathrm{E}$ ). This is the southeastern seaport region of the country. The Karnaphuli river areas are regarded as industrial and commercial hubs having more than 800 industrial establishments. They are adjacent to the sampling sites (BOBLME 2011). Chittagong ship breaking yard is the world's second largest ship breaking area confined to $18 \mathrm{~km}^{2}$ area along the coast of Sitakund Upazila (Bhatiary to Kumira in Chittagong division) in Bangladesh. During dismantling the ships, a huge amount of miscible and immiscible wastes are accumulated into the sediments of the coastal area.

The third site (St. 3) was located near the Meghna Estuary in Bhola (latitudes $22^{\circ} 28^{\prime} 07^{\prime \prime} \mathrm{N}$ to $22^{\circ} 20^{\prime} 39^{\prime \prime} \mathrm{N}$ and longitudes $90^{\circ} 49^{\prime} 4^{\prime \prime} \mathrm{E}$ to $90^{\circ} 50^{\prime} 3^{\prime \prime} \mathrm{E}$ ). This is the area where the main river descends together on to the Bay of Bengal carrying the industrial effluents through the descending rivers from the country and then the trans-boundary countries.

The site 4 (St. 4) was located near the southwest part of the Sundarbans area that is regarded as a large mangrove ecosystem area in Bangladesh (latitudes $22^{\circ} 34^{\prime} 43^{\prime \prime} \mathrm{N}$ to $22^{\circ} 18^{\prime} 02^{\prime \prime} \mathrm{N}$ and longitudes $89^{\circ} 32^{\prime} 48^{\prime \prime} \mathrm{E}$ to $89^{\circ} 36^{\prime} 26^{\prime \prime} \mathrm{E}$ ). This sampling area is also influenced by different anthropogenic activities like cement factories, export processing zone, sea port, paper industries, oil refinery industries, steal rerolling, fertilizer industry, hatcheries and aquafarms, fish processing industries, leather industries, dyeing industries and paint industries establishments (Table S1).

The sampling was conducted in two distinct seasons, summer $(\mathrm{S}, \mathrm{n}=18)$ and winter $(\mathrm{W}, \mathrm{n}=18)$. The summer samples were collected during the transition of summer and rainy season starting from early August to early September and the winter samples were collected from early January to early February in 2014. The tide in the coastal and estuarine area was semi-diurnal (two nearly equal high and low tides 
each day) and the samples were collected during the period of low tide. Unfiltered surface water samples were collected from four coastal sampling sites with three different stations of each. Immediately after collection, the samples were transferred into $100 \mathrm{ml}$ polypropylene bottles which were previously washed with dilute nitric acid and deionized water. Then the samples were stored in a refrigerator in the laboratory of the Department of Fisheries, University of Dhaka, Bangladesh. All processed samples were sent to Yokohama National University, Japan for chemical analysis under the permission of Yokohama Plant Protection Station.

Table S1. Location coordinates and site descriptions of the sampling stations in the coastal area of Bangladesh.

\begin{tabular}{|c|c|c|c|}
\hline Site & Latitude & Longitude & Site descriptions \\
\hline $\begin{array}{l}\text { Cox's Bazar (St1) } \\
\text { a. Bakkhali estuary } \\
\text { b. Hatchery area }\end{array}$ & $\begin{array}{l}21^{0} 27^{\prime} 02^{\prime \prime} \mathrm{N}- \\
21^{0} 26^{\prime} 33^{\prime \prime} \mathrm{N}\end{array}$ & $\begin{array}{l}91^{0} 58^{\prime} 16^{\prime \prime} \mathrm{E}- \\
91^{0} 57^{\prime} 01^{\prime \prime} \mathrm{E}\end{array}$ & $\begin{array}{l}\text { Seaside town with an unbroken } 125 \mathrm{~km} \text { world's longest natural } \\
\text { sandy sea beach. Fishing port and landing center, Fish hatcheries } \\
\text { and aquafarms, ship and boat making industries, paint industries, } \\
\text { salt industries, fish processing zone, garments, unplanned } \\
\text { urbanization, huge hotel and tourism (gather huge people). }\end{array}$ \\
\hline $\begin{array}{l}\text { Chittagong (St2) } \\
\text { a. Port area } \\
\text { b. Ship breaking area }\end{array}$ & $\begin{array}{l}22^{0} 13^{\prime} 27^{\prime \prime} \mathrm{N}- \\
22^{0} 38^{\prime} 22^{\prime \prime} \mathrm{N}\end{array}$ & $\begin{array}{l}91^{0} 48^{\prime} 14^{\prime \prime} \mathrm{E}- \\
91^{0} 32^{\prime} 45^{\prime \prime} \mathrm{E}\end{array}$ & $\begin{array}{l}\text { Southeastern region of the country, straddling the hills at the } \\
\text { estuary of the Karnaphuli river. Principal seaport regarded as } \\
\text { industrial and commercial hub. Oil refinery industries, ship } \\
\text { breaking industries, cement clinker industries, Triple Super } \\
\text { Phosphate (TSP) industries, Kornofully Fertilizer Company } \\
\text { (KAFCO); Urea industries, ammonia, steal rerolling, Kornofully } \\
\text { paper mill, export processing zone, garments industries, } \\
\text { hatcheries, Fish processing industries, leather industries, dyeing } \\
\text { industries, paint industries, rechargeable batteries, foundry } \\
\text { products, jewelry, plating, gas turbines and automobile engine } \\
\text { industries, electronics. }\end{array}$ \\
\hline $\begin{array}{l}\text { Meghna estuary, } \\
\text { Bhola (St3) }\end{array}$ & $\begin{array}{l}22^{0} 28^{\prime} 07^{\prime \prime} \mathrm{N}- \\
22^{0} 20^{\prime} 39^{\prime \prime} \mathrm{N}\end{array}$ & $\begin{array}{l}90^{0} 49^{\prime} 41^{\prime \prime} \mathrm{E}- \\
90^{\circ} 50^{\prime} 31^{\prime \prime} \mathrm{E}\end{array}$ & $\begin{array}{l}\text { Estuarine areas where the rivers mix together to sea containing the } \\
\text { industrial effluents through inland rivers from country and trans } \\
\text { boundary countries. }\end{array}$ \\
\hline $\begin{array}{l}\text { Sunderbans (St4) } \\
\text { Khulna and Bagerhat } \\
\text { (Mongla) region }\end{array}$ & $\begin{array}{l}22^{0} 34^{\prime} 43^{\prime \prime} \mathrm{N}- \\
22^{0} 18^{\prime} 02^{\prime \prime} \mathrm{N}\end{array}$ & $\begin{array}{l}89^{0} 32^{\prime} 48^{\prime \prime} \mathrm{E}- \\
89^{0} 36^{\prime} 26^{\prime \prime} \mathrm{E}\end{array}$ & $\begin{array}{l}\text { Cement factories, Tata company (coal electric industry), gas field, } \\
\text { export processing zone, sea port, paper industries, oil refinery } \\
\text { industries, ship breaking and repairing industries, steal rerolling, } \\
\text { tin industries, fertilizer industry, hatcheries and aquafarms, fish } \\
\text { processing industries, leather industries, dyeing industries, paint } \\
\text { industries, foundry products, jewelry, plating, gas turbines etc. }\end{array}$ \\
\hline
\end{tabular}

The physicochemical parameters, such as $\mathrm{pH}$, salinity, suspended solids (SS) and temperature (Temp.) of water were measured immediately after sample collection with a multi water quality checker (U-50, Horiba, Japan). For the analysis of percent carbon $(\% \mathrm{C})$ and percent nitrogen $(\% \mathrm{~N})$ in sediment samples, about $1.33 \mathrm{~g}$ of dried sediment samples of each was analyzed using an organic elemental analyzer (Macro Coder JM1000CN, J-Science Lab Co., Ltd., Japan). Different concentrations (20, 35, 50, 70 and $85 \mathrm{mg}$ ) of Hippuric acid (standard) were used to prepare the calibration curves of carbon (C) and nitrogen $(\mathrm{N})$. The percentages of $\mathrm{C}$ and $\mathrm{N}$ in the sediment samples were determined by external calibration method.

A microwave digestion was used to digest the samples for analysis. All chemicals were analytical grade reagents and Milli-Q (Elix UV5 and Milli-Q Adv.A10, Millipore, USA) water was used for each 
solution preparation. The PTFE (polytetrafluoroethylene) digestion vessels and polypropylene containers were cleaned, soaked in $5 \% \mathrm{HNO}_{3}$ for more than $24 \mathrm{~h}$, then rinsed with Milli-Q water and dried. For metal analysis, $20 \mathrm{ml}$ water sample of each were treated with $5 \mathrm{ml}$ of $69 \% \mathrm{HNO}_{3}$ (Kanto

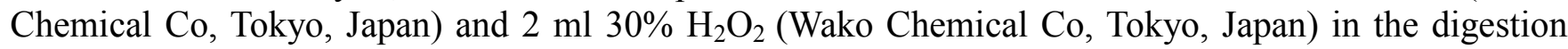
vessels. By stirring carefully with a teflon bar, the vessels containing mixtures were kept undisturbed for 20 minutes in the draft chamber (Fumehood, CBZ-Vc18-H1, Shimadzu, Japan). Then the vessels were placed in a microwave digestion system (Berghof-MWS2, Berghof speedwave ${ }^{\mathbb{B}}$, Germany). The following microwave program was applied: $10 \mathrm{~min}$ at $180{ }^{\circ} \mathrm{C}$ with $800 \mathrm{~W}, 10 \mathrm{~min}$ at $190{ }^{\circ} \mathrm{C}$ with $900 \mathrm{~W}$, and as a last step $10 \mathrm{~min}$ at $100{ }^{\circ} \mathrm{C}$ with $400 \mathrm{~W}$. After digestion, acid solutions with samples were transferred into a Teflon graduated cylinder and total volume was made up to $50 \mathrm{ml}$ with Milli-Q water. The digested acid solutions were then filtered by using a syringe filter (DISMIC ${ }^{\circledR}-25$ HP PTFE, pore size $=0.45 \mu \mathrm{m}$; Toyo Roshi Kaisha, Ltd., Tokyo Japan) and stored in $50 \mathrm{ml}$ polypropylene tubes (Nalgene, NY, USA).

Table 1. Operating conditions for ICP-MS and parameters for metal analysis.

\begin{tabular}{ll}
\hline Operating conditions & \\
\hline Nebulizer pump (rps) & 0.1 \\
RF power (W) & 1550 \\
Rf frequency & $27.12 \mathrm{MH}_{\mathrm{Z}}$ \\
Sample depth (mm) & $9 \mathrm{~mm}$ from load coil \\
Plasma gas flow rate (L/min) & 15 \\
Make up gas flow rate & $\mathrm{Ar} 0 \mathrm{~L} / \mathrm{min}$ \\
Carrier gas (Ar) flow rate (L/min) & 1.0 (optimized daily) \\
Collision gas mode & $\mathrm{He} 4.0 \mathrm{~mL} / \mathrm{min}$ \\
Measurement parameters & \\
Scanning mode & Peak hop \\
Resolution (amu) & 0.7 \\
Readings/replicate & 1 \\
No. of replicates & 3 \\
Correction equations for interferences & $\mathrm{Li}[6]:[6] * 1-[7] * 0.082$ \\
& $\mathrm{In}[115]:(115) * 1-[118] * 0.014$ \\
Isotopes & $\mathrm{Pb}[208]:[208] * 1+[206] * 1+[207] * 1$ \\
& ${ }^{52} \mathrm{Cr},{ }^{60} \mathrm{Ni},{ }^{63} \mathrm{Cu},{ }^{65} \mathrm{Zn},{ }^{75} \mathrm{As},{ }^{11} \mathrm{Cd},{ }^{20} \mathrm{~Pb}$ \\
\hline
\end{tabular}

For trace metals, samples were analyzed using inductively coupled plasma mass spectrometer (ICPMS, Agilent 7700 series, USA) (Table 1). Multi-element Standard XSTC-13 (SPEX CertiPrep ${ }^{\circledR}$, USA) solutions were used to prepare calibration curve. The calibration curves with $\mathrm{R}^{2}>0.999$ were accepted for concentration calculation. Before starting the sequence, relative standard deviation ( $\mathrm{RSD}<5 \%$ ) was checked by using tuning solution $\left(1 \mu \mathrm{g} / \mathrm{l}\right.$ each of $\mathrm{Li}, \mathrm{Y}, \mathrm{Ce}, \mathrm{Tl}, \mathrm{Mg}$ and $\mathrm{Co}$ in $2 \mathrm{wt} \% \mathrm{HNO}_{3}$ ) purchased from Agilent Technologies.

Internal calibration standard solution containing $1.0 \mathrm{mg} / 1$ each of Beryllium $(\mathrm{Be})$ and Tellurium $(\mathrm{Te})$, and $0.5 \mathrm{mg} / 1$ each of Indium (In), Yttrium (Y), Cobalt (Co) and Thallium (TI) was purchased from SPEX CertiPrep ${ }^{\circledR}$, USA and it was added into each sample. Working standards $(0,10,20,50$ and 100 $\mu \mathrm{g} / \mathrm{l}$ ) were prepared by dilution of a multi-element stock solution (Custom Assurance Standard, SPEX CertiPrep $^{\circledR}$, USA), then the concentrations of trace metals were determined by an internal standard method. All test batches were evaluated using an internal quality approach and validated if they satisfied the defined Internal Quality Controls (IQCs). For each batch experiment, one blank, one certified reference material (CRM) and several samples were analyzed in duplicate to eliminate any batch-specific error. Finally, the concentration of trace metals were quantified by calibration based on internal standards. 
The data were analyzed by using the statistical package, IBM SPSS 22.0 (NY, USA). A Pearson bivariate correlation was used to evaluate the relationship among the inter-elemental and physicchemical parameters. Both $p$ value $<0.05$ and $<0.01$ were considered.

\section{RESULTS AND DISCUSSION}

Mean values of seasonal variation of physical-chemical parameters and metal concentrations of different coastal water samples are shown in Tables 2 and 3 and Figure 2 (a, b). A wide range and variation of metal concentrations were observed among the sampling sites. Factors such as salinity, SS, TOC, pH, Temp., anthropogenic inputs, geomorphological setup, and terrestrial runoff might have played a role in the variation of metal distribution in relation to seasonal vagaries.

Table 2. Seasonal variation of physical-chemical parameters in water samples (Mean $\pm \mathrm{SD})$.

\begin{tabular}{llllcccccc}
\hline Sampling sites & & \multicolumn{3}{c}{ pH } & \multicolumn{2}{c}{ T $\left({ }^{\circ} \mathbf{C}\right)$} & \multicolumn{2}{c}{ Salinity (\%) } & \multicolumn{2}{c}{ SS (mg/L) } \\
\cline { 3 - 9 } & & S & W & S & W & S & W & S & W \\
\hline St. 1. (a) Cox's Bazar Bakkhali & Mean & 6.0 & 7.2 & 22 & 21 & 12 & 27 & 110 & 360 \\
estuary (n=3) & SD & 0.5 & 1.5 & 1.3 & 1.3 & 5.7 & 9.7 & 52.9 & 156 \\
\hline St. 1. (b) Cox's Bazar Hatchery & Mean & 5.8 & 7.9 & 22 & 20 & 23 & 21 & 413 & 157 \\
(n=3) & SD & 0.8 & 0.3 & 0.6 & 1.4 & 0.9 & 6.9 & 163 & 30.6 \\
\hline St. 2. (a) Chittagong port (n=3) & Mean & 5.3 & 6.9 & 24 & 21 & 16 & 24 & 497 & 193 \\
& SD & 0.8 & 0.4 & 0.3 & 1.3 & 2.3 & 3.0 & 55.1 & 40.4 \\
\hline St. 2. (b) Chittagong ship breaking & Mean & 4.7 & 7.0 & 25 & 21 & 17 & 16 & 552 & 130 \\
(n=3) & SD & 0.8 & 1.1 & 1.0 & 1.0 & 1.5 & 1.3 & 85.5 & 60.8 \\
\hline St. 3. Meghna estuary, Bhola (n=3) & Mean & 7.7 & 8.0 & 23 & 20 & 5 & 6 & 673 & 1387 \\
& SD & 1.0 & 0.04 & 0.6 & 1.6 & 2.5 & 1.7 & 201 & 15724 \\
\hline St. 4. Sundarbans (n=3) & Mean & 6.0 & 6.7 & 23 & 21 & 5 & 8 & 1220 & 927 \\
& SD & 0.5 & 1.8 & 0.8 & 2 & 2.6 & 1 & 312 & 304 \\
\hline & & S=summer, W=winteryyyyyyyyyyyyyyy
\end{tabular}

The mean concentration of trace metals in water samples were in the range of $\mathrm{Cr}(2.6-15.3), \mathrm{Ni}$ (5.1-77.5), $\mathrm{Cu}$ (10.2-510), Zn (5.0-1390), As (2.1-13.3), Cd (0.006-0.09), Pb (0.4-109 $\mu \mathrm{g} / \mathrm{L})$, in summer (S) and $\mathrm{Cr}$ (3.6-43.7), Ni (10.8-42.4), $\mathrm{Cu}$ (7.3-45.2), Zn (18.0-73.9), As (4.0-19.7), Cd (0.025-0.087), $\mathrm{Pb}(2.8-34.8 \mu \mathrm{g} / \mathrm{L})$ in winter $(\mathrm{W})$. The mean concentrations of the studied metals in water followed decreasing order like $\mathrm{Zn}>\mathrm{Cu}>\mathrm{Pb}>\mathrm{Ni}>\mathrm{Cr}>\mathrm{As}>\mathrm{Cd}$ in summer and $\mathrm{Zn}>\mathrm{Ni}>\mathrm{Cr}>$ $\mathrm{Cu}>\mathrm{Pb}>\mathrm{As}>\mathrm{Cd}$ in winter. The water of Cox's Bazar hatchery site showed the highest levels of $\mathrm{Zn}$ (1390), $\mathrm{Cu}(510)$ and $\mathrm{Pb}(109 \mu \mathrm{g} / \mathrm{l})$ in summer (Table 3, Figure 2a) while As (19.7 $\mu \mathrm{g} / 1)$ showed highest in Cox's Bazar Bakkhali estuary in winter samples (Table 3, Fig. 2b). Elevated level of Ni (77.5 $\mu \mathrm{g} / \mathrm{l})$ in summer and $\mathrm{Cr}(43.7 \mu \mathrm{g} / \mathrm{l})$ in winter were also found in Sundarbans site (Table 3, Fig. $2 \mathrm{a}$ and b).

Cox's Bazar Hatchery site was very close to the sandy sea beach along with the sampling sites where more than 53 shrimp hatcheries and aquafarms, big fish landing centers, ship repairing, painting and coating; huge hotels for amusement of tourists and industries were located. During the summer, the fish processing, aquafarm operation, hatcheries, crop cultivation and other industrial activities are robustly increased in the sampling sites. The high metal concentrations in this particular period might be attributed to discharge of different salts and chemicals from hatcheries, fish processing industries and aqua farms through their underground pipeline outlets to the sea without treatment. Besides, most of the domestic, municipal sewages and industrial effluents of Cox's Bazar city are incorporated to the Bakkhali River through different uncontrolled canals to the Sea. The waste discharge and chemical spills associated with boat repairing industries represent an additional source of pollutants to the water and sediments in this area. 
Table 3. Seasonal variation of metal concentrations $(\mu \mathrm{g} / \mathrm{L})$ in water samples $($ Mean $\pm \mathrm{SD})$.

\begin{tabular}{|c|c|c|c|c|c|c|c|c|c|c|c|c|c|c|c|}
\hline \multirow[t]{2}{*}{ Sampling sites } & & \multicolumn{2}{|c|}{$\mathrm{Cr}$} & \multicolumn{2}{|c|}{$\mathbf{N i}$} & \multicolumn{2}{|c|}{$\mathbf{C u}$} & \multicolumn{2}{|c|}{$\mathbf{Z n}$} & \multicolumn{2}{|c|}{ As } & \multicolumn{2}{|c|}{ Cd } & \multicolumn{2}{|c|}{$\mathbf{P b}$} \\
\hline & & $\mathbf{S}$ & $\mathbf{W}$ & $\mathbf{S}$ & $\mathbf{W}$ & $\mathbf{S}$ & $\mathbf{W}$ & $\mathbf{S}$ & $\mathbf{W}$ & $\mathbf{S}$ & $\mathbf{W}$ & $\mathbf{S}$ & $\mathbf{W}$ & $\mathbf{S}$ & $\mathbf{W}$ \\
\hline St. 1. (a) Cox's Bazar & Mean & 2.6 & 30.8 & 5.1 & 35.4 & 239 & 23.4 & 12.4 & 60.4 & 5.9 & 19.7 & 0.016 & 0.06 & 0.3 & 14.1 \\
\hline Bakkhali estuary $(n=3)$ & SD & 0.3 & 23.4 & 1.1 & 20.1 & 229 & 11.4 & 11.9 & 45.5 & 4.1 & 4.5 & 0.01 & 0.01 & 0.4 & 10.9 \\
\hline St. 1. (b) Cox’s Bazar & Mean & 8.8 & 3.6 & 12.4 & 10.8 & 510 & 10.6 & 1390 & 18.6 & 9.0 & 13.4 & 0.092 & 0.05 & 109 & 34.8 \\
\hline Hatchery $(n=3)$ & $\mathrm{SD}$ & 10.9 & 0.6 & 11.2 & 2.7 & 336 & 8.2 & 2391 & 15.9 & 3.0 & 9.6 & 0.1 & 0.03 & 189 & 52.4 \\
\hline St. 2. (a) Chittagong port & Mean & 8.3 & 12.2 & 9.0 & 14.8 & 20.3 & 11.9 & 5.5 & 18.0 & 2.3 & 11.4 & 0.006 & 0.05 & 2.6 & 3.7 \\
\hline$(\mathrm{n}=3)$ & $\mathrm{SD}$ & 2.6 & 2.3 & 2.7 & 2.5 & 4.9 & 1.2 & 7.1 & 1.3 & 0.4 & 0.4 & 0.003 & 0.01 & 0.9 & 0.9 \\
\hline St. 2. (b) Chittagong ship & Mean & 6.3 & 7.3 & 12.3 & 13.3 & 14.3 & 7.3 & 17.1 & 20.5 & 13.3 & 14.9 & 0.04 & 0.05 & 3.6 & 2.8 \\
\hline breaking $(\mathrm{n}=3)$ & SD & 2.1 & 3.1 & 3.9 & 3.6 & 5.5 & 7.1 & 5.5 & 8.3 & 4.4 & 1.2 & 0.02 & 0.01 & 2.6 & 2.4 \\
\hline St. 3. Meghna estuary, & Mean & 11.8 & 21.5 & 10.5 & 22.8 & 10.2 & 19.8 & 5.0 & 36.0 & 2.1 & 4.0 & 0.01 & 0.02 & 5.8 & 8.5 \\
\hline Bhola $(n=3)$ & $\mathrm{SD}$ & 1.4 & 20.1 & 1.8 & 20.4 & 13.9 & 17.0 & 8.2 & 29.2 & 0.1 & 1.28 & 0.001 & 0.02 & 1.5 & 8.8 \\
\hline St. 4. Sundarbans $(n=3)$ & Mean & 15.3 & 43.7 & 77.5 & 42.4 & 163 & 45.2 & 342 & 73.9 & 2.3 & 9.4 & 0.03 & 0.09 & 6.9 & 24.2 \\
\hline & SD & 5.5 & 15.2 & 112 & 14.0 & 281 & 183 & 572 & 25.7 & 0.4 & 1.24 & 0.03 & 0.02 & 2.3 & 9.2 \\
\hline
\end{tabular}

In common, zinc oxide $(\mathrm{ZnO})$ is roughly used in aqua farms and hatcheries for oxygen supply to fry and fingerlings (Shamsuzzaman and Biswas 2012). Considering ship repairing, painting and coating, a huge amount of commercial paints containing zinc oxide $(\mathrm{ZnO})$ and zinc sulphide $(\mathrm{ZnS})$ have long been used as anticorrosive coatings in different type of boats, fishing trawlers and ships in Cos'x Bazar and Chittagong coast to protect the wood and steel structures of these water vehicles. Zinc sulphate $\left(\mathrm{ZnSO}_{4}\right)$ and zinc chloride $\left(\mathrm{ZnCl}_{2}\right)$ are widely used in textile industries like dyeing, printing, sizing and weighting of fabrics (Stellman 1998). So, the significant amount of $\mathrm{Zn}$ was contributed by the ship repairing, painting, textile dyeing and vulcanization process to this area. Besides, $\mathrm{Cu}$ has been used as disinfectant chemical in hatcheries, aquatic farms and aquaculture operations. It is broadly used as an effective algaecide and in some parasites treatment. The cheapest and most commonly used form is copper sulfate $\left(\mathrm{CuSO}_{4}\right)$ (Watson and Yanong 1989, Shamsuzzaman and Biswas 2012).

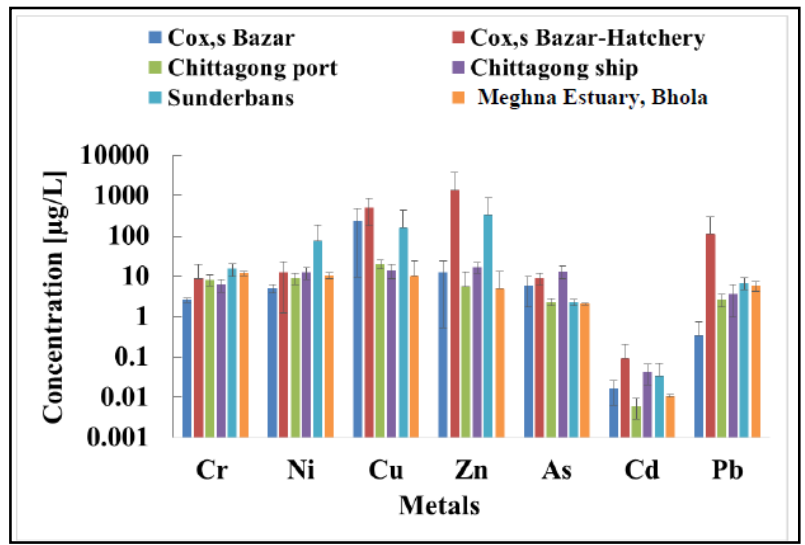

a

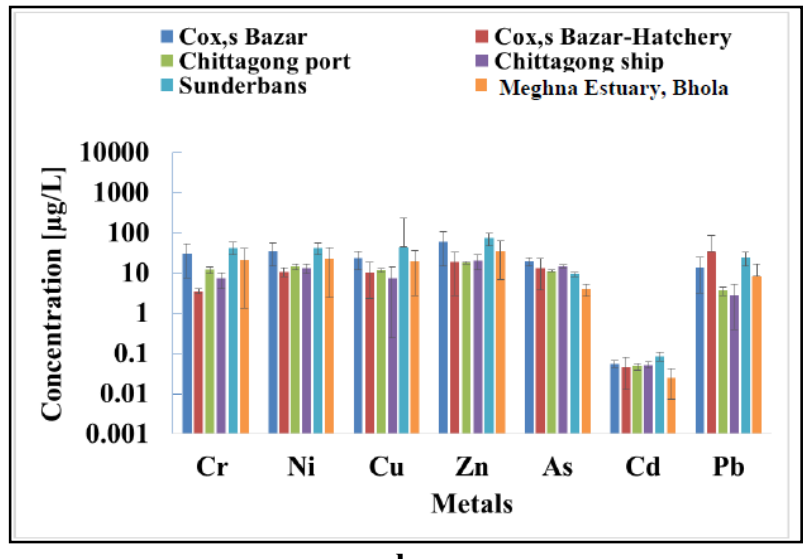

b

Fig. 2. Seasonal distribution of trace metals concentration $(\mu \mathrm{g} / \mathrm{L})$ in water samples $(\mathrm{n}=18)$ : a. summer; and $\mathbf{b}$. winter.

Moreover, $\mathrm{Pb}$ can be carried in water, either dissolved or as waterborne particles. The high concentration of $\mathrm{Pb}$ in this site might be attributed to the acid drainage from the industrial wastes and different chemical activities of hatcheries, fish processing, paint and ship repairing industries. The highest mean concentration of As was observed in water at Cox's Bazar Bakkhali estuary in the winter season. High As concentration might be attributed to anthropogenic activities, such as treatment of agricultural land with ground water for irrigation, fertilizers and arsenical pesticides (Renner 2004, 
Neumann et al. 2011, Fu et al. 2014). Emission and waste from brick fields and incineration activities might contribute additional concentration of As (Olawoyin et al. 2012). However, in coastal water, higher amount of arsenic comes mostly from the sediments deposited in the coastal sediment through the river system from the upland Himalayan catchments as well as the northern part of Bangladesh (Mitamura et al. 2008). However, the present study revealed that $\mathrm{Zn}, \mathrm{Cu}$ and $\mathrm{Pb}$ were much higher than the most quality guideline values (Table 5).

Among the sites, the highest mean concentration of $\mathrm{Ni}(77.5 \mu \mathrm{g} / \mathrm{l})$ in the summer and $\mathrm{Cr}(43.7 \mu \mathrm{g} / \mathrm{l})$ in the winter were observed in the water samples of the Sundarbans site (Table 3, Figures 2a, b) which is attributed to the different industrial activities of stainless steel, ship breaking and repairing, rechargeable batteries, foundry products, jewelry, metal ceramics, dyeing and leather industries, plating and gas turbine factories, export import zones in Khulna and Mongla port areas. Mostly, nickel is used in stainless steel which are characterized by strength, ductility, and resistance to corrosion and heat so that it is ideal for propeller shaft in boats and desalination plants. Basically, $\mathrm{Cr}$ is used in stainless steel to give polished silvery mirror coating, chrome plating, metallurgy to impart corrosion resistance, metal ceramics, shiny finish in dyes and paints, as a catalyst in dyeing and in the tanning of leather, to make molds for the firing of bricks and manufacture of magnetic tape. Chromium in water supplies is generally found in the hexavalent form which is highly toxic and in higher concentration to be carcinogenic (ATSDR 2012). We found that the mean concentration of $\mathrm{Ni}$ and $\mathrm{Cr}$ were much higher than the toxicity reference value (USEPA 1999, WHO 2004) (Table 4).

Table 4. Comparison of detected metal concentration $(\mu \mathrm{g} / \mathrm{L})$ in coastal water $(\mathrm{n}=3)$ with guideline values along with some reported values in the literature (Summer vs Winter).

\begin{tabular}{|c|c|c|c|c|c|c|c|c|}
\hline & $\mathrm{Cr}$ & $\mathbf{N i}$ & $\mathbf{C u}$ & $\mathbf{Z n}$ & As & $\mathbf{C d}$ & $\mathbf{P b}$ & References \\
\hline \multicolumn{9}{|l|}{ Metal range (Mean) } \\
\hline Summer & $2.6-15.3$ & $5.1-77.5$ & $10.2-510$ & $5.0-1390$ & $2.1-13.3$ & $0.006-0.09$ & $0.3-109$ & (Present study) \\
\hline Winter & $3.6-43.7$ & $10.8-42.4$ & $7.3-45.2$ & $18.0-73.9$ & $4.0-19.7$ & $0.025-0.087$ & $2.8-34.8$ & (Present study) \\
\hline \multicolumn{9}{|l|}{ Marine water ${ }^{\mathrm{a}}$} \\
\hline 1. Industrial harbor & $0.1-0.5$ & $0.1-12$ & $0.5-10$ & $0.5-20$ & $1-40$ & $0.001-0.5$ & $<0.002-3$ & \\
\hline 2. Coastal \& ocean & $0.03-0.3$ & $0.1-0.2$ & $0.02-0.07$ & $0.01-0.5$ & $0.5-1.5$ & $<0.001-0.08$ & $<0.001-0.2$ & \\
\hline \multicolumn{9}{|l|}{ Quality of water* } \\
\hline 1. Limited & & & 40 & 80 & 50 & 5 & 20 & BOJA num, 1997 \\
\hline 2. No limited & & & 20 & 60 & 25 & 2.5 & 10 & BOJA num, 1997 \\
\hline \multirow[t]{3}{*}{ Drinking water } & 50 & 100 & 1000 & & 50 & 5 & 50 & DoE,(DWSB), 1997 \\
\hline & 11 & 52 & 9 & & 150 & 2.2 & 2.5 & TRV, USEPA, 1999 \\
\hline & 5 & 70 & 2000 & & 10 & 3 & 10 & WHO-2004 \\
\hline
\end{tabular}

a Apte et al. (1998); Hatje et al. (2003); Angel et al. (2010); 'Imperative values (total metal) proposed by Andalusia Government (Spain); 1. Limited = Tinto and Odiel point (river sites); 2. No limited = Canal del Padre Santo point (Ría de Huelva estuary close to the Atlantic Ocean); DWSB = Drinking Water Standard for Bangladesh proposed through ECR (Department of Environment, DoE); USEPA = United States Environmental Protection Agency; TRV = Toxicity Reference Value; Cox. = Cox's Bazar, Ctg. = Chittagong, Sun. = Sundarbans, Bhola = Meghna estuary.

The highest $\mathrm{Cd}(0.092 \mu \mathrm{g} / \mathrm{l})$ was observed in water at Cox's Bazar site in the summer and similar concentration was also found at the Sundarbans site in the winter which might be attributed from different electroplating industries, ship repairing, and battery dumping. Besides, weathering of rocks, manures, municipal sewage sludge, fossil fuel combustion, artificial phosphate fertilizers (Alloway and Steinnes 1999, Sheppard et al. 2009) and pesticides also contribute significant amount of Cd in this area. Cadmium is produced as an impurity of phosphate fertilizers (Savci 2012). $\mathrm{CdSO}_{4}$ is also frequently used in pesticide production (OSHA 1993). Annually, approximately 45,172.43 tons of pesticides and 2,234,000 (mt.) of fertilizers in 2009 were being used in this coastal area (BOBLME 2011). 
However, the main course of the river Padma continues to the south and is joined with the Brahmaputra and then with the Meghna before entering the Bay of Bengal. Considering the bay of Meghna estuary, it measures $30 \mathrm{~km}(20 \mathrm{mi})$ wide. The average annual discharge of the water of this river system is surpassed by the Amazon and Congo rivers. Because the discharge includes large deposits of sediment and different types of pollutants, the delta continues to expand into the bay. The mean concentrations of $\mathrm{Cr}, \mathrm{Ni}, \mathrm{Cu}, \mathrm{Zn}, \mathrm{As}, \mathrm{Cd}$ and $\mathrm{Pb}$ in the winter water samples were 21.85, 22.8,19.8,36.0,4.0, 0.02 and $8.5 \mu \mathrm{g} / 1$, respectively which were higher than the summer water samples like 11.8,10.5,10.2,5.0,2.1,0.01 and $5.8 \mu \mathrm{g} / \mathrm{l}$, respectively. Among all the metal concentrations in the water samples of this estuary, the highest concentration of $\mathrm{Zn}(36.0 \mu \mathrm{g} / \mathrm{l})$ were observed in the winter water sample.

In Bangladesh, seasons are very important for the fisheries, agriculture expansion, industrial activities and above all anthropogenic inputs into the coastal area. This coastal environment especially the biological and geochemical conditions have been contaminated and influenced by these persistent pollutants of fisheries, agriculture and industrial origin to a considerable extent. Factors, such as total organic carbon (TOC), suspended solid (SS), temperature, rainfall, anthropogenic inputs and above all geomorphological setup are influenced by seasonal vagaries which might have played a vital role in the variation of metal distribution in this tropical estuarine system. Significant higher metal concentrations especially $\mathrm{Zn}, \mathrm{Cu}$ and $\mathrm{Pb}$ were found in Cox's Bazar site in summer than in winter seasons. Similar observation on seasonal metal distribution in the water of the Lake Manzala, Egypt was also observed in the studies of Bahnasawy et al. 2009. During the summer, industrial and agricultural activities like fish processing, aquafarm operation, hatcheries, crop cultivation and ship dismantling activities are vigorously increased in the sampling sites. The high metal concentration in this particular period might be attributed to discharge of different salts and chemicals from hatcheries, fish processing aqua farms and different industries. Huge inclusion of domestic, municipal sewages and industrial effluents through Bakkhali estuary to coastal area represented an additional source of pollutants. However, the increase of metal concentrations in water during the summer to the release of trace metals from sediment to the overlying water was under the effect of both high temperature and fermentation process (Ali and AbdelSatar 2005).

Statistical analyses were accomplished in order to clarify the relations among the metals and physical-chemical parameters in the water samples. Inter-metal interactions may illustrate the sources and pathways of the metals present in the particulate media. Pearson's correlations among the metals and physical-chemical parameters were analyzed $(\mathrm{p}<0.05$ and $\mathrm{p}<0.01)$ and shown in Tables 5 and 6 .

Considering the summer samples, the extreme large value of $\mathrm{Zn}(1390 \mu \mathrm{g} / \mathrm{l})$ in the water of Cox's Bazar Hatchery site (Table 3) somewhat influence the Pearson correlation coefficient matrix for some trace metals acting as outlier (was confirmed by box and whisker plot test in SPSS V22). The value was notably different from the rest of the data and it already altered the results of the data analysis. Therefore, for statistical analysis, it was important to consider the exclusion of aforesaid outlier within this distribution due to avoid the large influence on existence and to show the stability and robustness of those analyses. Thus, the analysis was revealed the following relationships: $\mathrm{Cu}$ and As were positively correlated with salinity whereas $\mathrm{Cr}$ and $\mathrm{Ni}$ were positively correlated with suspended solids (SS). Remarkably, no correlation of $\mathrm{pH}$ and temperature with total metal concentrations was observed. Comparing inter-metal interactions, $\mathrm{Cr}$ showed a positive correlation with $\mathrm{Ni}, \mathrm{Cd}$ and $\mathrm{Pb}$; $\mathrm{Zn}$ showed a significant correlation with $\mathrm{Cd}$ while $\mathrm{Cd}$ was positively correlated with $\mathrm{Pb}$. Negative correlation of $\mathrm{pH}$ with Temp. $(\mathrm{r}(\mathrm{x}, \mathrm{y})=-0.542)$ and with salinity $(\mathrm{r}(\mathrm{x}, \mathrm{y})=-0.568)$ was found (Table 5). 
Table 5. Pearson correlation coefficient matrix for trace metals and physicochemical parameter in water samples $(\mathrm{n}=18$, summer).

\begin{tabular}{|c|c|c|c|c|c|c|c|c|c|c|c|}
\hline & pH & Temp. & Salinity & SS & $\mathrm{Cr}$ & $\mathbf{N i}$ & $\mathrm{Cu}$ & $\mathbf{Z n}$ & As & Cd & $\mathbf{P b}$ \\
\hline $\mathrm{pH}$ & 1 & & & & & & & & & & \\
\hline Temp. & $-0.542^{*}$ & 1 & & & & & & & & & \\
\hline Salinity & $-0.568^{*}$ & 0.107 & 1 & & & & & & & & \\
\hline SS & 0.165 & 0.211 & $-0.483^{*}$ & 1 & & & & & & & \\
\hline $\mathrm{Cr}$ & 0.228 & 0.100 & -0.340 & 0.630 ** & 1 & & & & & & \\
\hline $\mathrm{Ni}$ & -0.096 & 0.147 & -0.198 & $0.689^{* *}$ & $0.577 *$ & 1 & & & & & \\
\hline $\mathrm{Cu}$ & -0.019 & -0.378 & $0.489 *$ & 0.019 & -0.069 & 0.311 & 1 & & & & \\
\hline $\mathrm{Zn}$ & -0.437 & 0.049 & 0.181 & -0.173 & -0.100 & 0.298 & 0.045 & 1 & & & \\
\hline As & -0.437 & 0.321 & $0.618^{* *}$ & -0.239 & -0.402 & -0.152 & 0.299 & 0.378 & 1 & & \\
\hline $\mathrm{Cd}$ & -0.187 & -0.007 & 0.427 & -0.057 & $0.523 *$ & 0.257 & 0.281 & $0.503^{*}$ & 0.141 & 1 & \\
\hline $\mathrm{Pb}$ & 0.031 & -0.166 & 0.350 & -0.155 & $0.549 *$ & 0.043 & 0.186 & -0.121 & -0.021 & $0.923^{* *}$ & 1 \\
\hline
\end{tabular}

*Correlation is significant at the 0.05 level (2-tailed); ${ }^{* *}$ Correlation is significant at the 0.01 level (2-tailed).

Considering the winter samples, the analysis revealed the following relationships: As was positively correlated with salinity whereas $\mathrm{Cr}$, Ni and $\mathrm{Zn}$ were positively correlated with suspended solids (SS). No positive correlation was found between $\mathrm{pH}$ and temperature in terms of total metal concentrations. Comparing Inter-metal interactions, $\mathrm{Cr}$ showed a positive correlation with $\mathrm{Ni}, \mathrm{Cu}$ and $\mathrm{Zn}$; $\mathrm{Zn}$ showed a significant correlation with $\mathrm{Cd}$ which was positively correlated with $\mathrm{Cu}, \mathrm{Zn}, \mathrm{As}$ and $\mathrm{Pb}$. Negative correlation of temperature with $\mathrm{Pb}(\mathrm{r}(\mathrm{x}, \mathrm{y})=-0.476)$ and of salinity with $\mathrm{SS}(\mathrm{r}(\mathrm{x}, \mathrm{y})=-0.532)$ were found (Table 6). Higher correlation coefficient between the metals indicated identical sources, mutual dependence and identical behavior during their transport in water (Singh et al. 2002) while negative correlation showing a non-identical behavior of these metals in coastal environment (Braungardt et al. 2003).

Table 6. Pearson correlation coefficient matrix for trace metals and physicochemical parameter in water samples $(\mathrm{n}=18$, winter).

\begin{tabular}{|c|c|c|c|c|c|c|c|c|c|c|c|}
\hline & pH & $\mathbf{T}$ & Salinity & SS & $\mathbf{C r}$ & $\mathbf{N i}$ & $\mathbf{C u}$ & $\mathbf{Z n}$ & As & Cd & $\mathbf{P b}$ \\
\hline $\mathrm{pH}$ & 1 & & & & & & & & & & \\
\hline $\mathrm{T}$ & 0.23 & 1 & & & & & & & & & \\
\hline Salinity & -0.22 & -0.043 & 1 & & & & & & & & \\
\hline SS & 0.12 & -0.2 & $-.532 *$ & 1 & & & & & & & \\
\hline $\mathrm{Cr}$ & 0.09 & -0.012 & -0.267 & $.652 * *$ & 1 & & & & & & \\
\hline $\mathrm{Ni}$ & 0.094 & -0.063 & -0.163 & $.630 * *$ & $.986^{* *}$ & 1 & & & & & \\
\hline $\mathrm{Cu}$ & 0.14 & 0.384 & -0.238 & 0.321 & $.513 *$ & $.477 *$ & 1 & & & & \\
\hline $\begin{array}{l}\mathrm{Zn} \\
\text { As }\end{array}$ & $\begin{array}{c}0.18 \\
-0.281\end{array}$ & $\begin{array}{c}-0.121 \\
-0.12\end{array}$ & $\begin{array}{c}-0.23 \\
.800^{* *}\end{array}$ & $\begin{array}{l}.525^{*} \\
-0.37\end{array}$ & $\begin{array}{l}.911 * * \\
-0.043\end{array}$ & $\begin{array}{l}.919 * * \\
0.083\end{array}$ & $\begin{array}{l}0.466 \\
-0.09\end{array}$ & $\begin{array}{c}1 \\
0.102\end{array}$ & 1 & & \\
\hline $\mathrm{Cd}$ & -0.179 & 0.08 & 0.208 & 0.034 & 0.432 & 0.464 & $.501 *$ & $.574 *$ & $.574 *$ & 1 & \\
\hline $\mathrm{Pb}$ & 0.113 & $-.476 *$ & 0.208 & 0.093 & 0.148 & 0.216 & 0.175 & 0.347 & 0.468 & $.515^{*}$ & 1 \\
\hline
\end{tabular}

*Correlation is significant at the 0.05 level (2-tailed); **Correlation is significant at the 0.01 level (2-tailed).

This study was assigned to provide base line information on the seasonal variation in the concentrations of some toxic trace metals in the water samples collected from different coastal sites. 
Among the four sites studied, the water of Cox's Bazar hatchery site was more polluted where the elevated concentrations of $\mathrm{Zn}, \mathrm{Cu}$ and $\mathrm{Pb}$ were observed in the summer (except $\mathrm{Cr}$ and $\mathrm{As}$ for the winter). Interestingly, highest As concentration was observed in Cox's Bazar Bakkhali estuary in the winter. The concentrations were compared with quality guideline values where they exceeded the standard limit. The factors, such as temperature, rainfall, terrestrial runoff, anthropogenic inputs (e.g. fisheries, agricultural and industrial etc.) and above all geomorphological setup are influenced by seasonal vagaries which might have played a vital role in the variation of metal distribution in this tropical estuarine aquatic ecosystem. So, the elevated level of season based trace metal contaminations in water in Bangladeshi coastal ecosystem should not be ignored and this problem should be solved with an integrated approach. It is thus proposed that a continuous monitoring of these toxic trace elements in aquatic environmental media is needed to evaluate if any impending risks of the study area do exist.

\section{ACKNOWLEDGEMENTS}

The authors would like to acknowledge the Graduate School of Environment and Information Sciences, Yokohama National University, Japan for providing research grant through the International Environmental Leadership Program in Sustainable Living with Environmental Risk (SLER) under the aid of Strategic Funds for the Promotion of Science and Technology from the Ministry of Education, Culture, Sports, Science and Technology and through Research Collaboration Promotion Fund. The authors also would like to convey special thanks and gratitude to the Department of Fisheries, University of Dhaka for laboratory support.

\section{REFERENCES}

Ali, M. H. and A. M. Abdel-Satar. 2005. Studies of some heavy metals in water, sediment, fish and fish diets in some fish farms in El-Fayoum province, Egypt. J. Aquat. Res. 31(2): 261-273.

Alloway, B. J. and E. Steinnes. 1999. Anthropogenic additions of cadmium to soils. In: M. J. McLaughlin and B. R. Singh (eds). Cadmium in Soils and Plants. Kluwer Academic Publishers, Dordrecht., pp. 97-123.

Angel, B., L. T. Hales, S. L. Simpson, S. C. Apte, A. Chariton, D. Shearer and D. F. Jolley. 2010. Spatial variability of cadmium, copper, manganese, nickel and zinc in the Port Curtis Estuary, Queensland, Australia. Marine and Freshwater Research. 61:170-183.

Apte, S. C., G. E. Batley, R. Szymczak, P. S. Rendell, R. Lee and T. D. Waite. 1998. Baseline trace metal concentrations in New South Wales coastal waters. Marine and Freshwater Research. 49: 203-214.

ATSDR. 2012. Toxicological Profile for Chromium. Agency for Toxic Substances and Disease Registry, U. S. Department of Health and Human Services, Atlanta, GA. https://www.atsdr.cdc.gov/toxprofiles/tp7.pdf.

Bahnasawy, H. M., A. A. A. Khidr and N. A. Dheina. 2009. Assessment of heavy metals concentrations in water, plankton and fish of Lake Manzala, Egypt. Egypt J. Aquat. Biol. Fish. 13(2): 117-133.

BOBLME. 2011. Country report on pollution in the BOBLME-Bangladesh. BOBLME Ecology-01. http://www.boblme.org/documentRepository/BOBLME-2011-Ecology-01.pdf.

BOJA num. 1997. Orden de 14 de febrero de, por la que se clasifican las aguas afectadas directamente por vertidos, en desarrollo del Decreto 14/1996, de 16 de enero, por el que se aprueba el Reglamento de calidad de aguas litorales., pp. 2591-2598. 
Braungardt, B. B., E. P. Achterberg, F. Elbaz-Poulichet and N. H. Morley. 2003. Metal geochemistry in a mine polluted estuarine system in Spain. Appl. Geochem. 18: 1757-1771.

Copat, C., F. Bella, M. Castaing, R. Fallico, S. Sciacca and M. Ferrante. 2012. Heavy metals concentrations in fish from Sicily (Mediterranean Sea) and evaluation of possible health risks to consumers. Bull. Environ. Contamin. Toxicol. 88: 78-83.

DoE. 1997. The Environment Conservation Rules (ECR). Department of Environment, Government of the People's Republic of Bangladesh Bangladesh., pp. 179-226.

Ebrahimpour, M., A. Pourkhabbaz, R. Baramaki, H. Babaei and M. Rezaei. 2011. Bioaccumulation of heavy metals in freshwater fish species Anzali, Iran. Bull. Environ. Contamin. Toxicol. 87: 386-392.

Eisler, R. 1988. Zink Hazards to fish, Wildlife and Invertebrates: a synoptic review. U. S. Department of the Interior Fish and Wildlife Service Patuxent Wildlife Research Center, Laurel, Maryland-20708. $85 \mathrm{pp}$.

Fu, J., C. Zhao, Y. Luo, C. Liu, G. Z. Kyzas, Y. Luo, D. Zhao, S. An and H. Zhu. 2014. Heavy metals in surface sediments of the Jialu River, China: Their relations to environmental factors. J. Hazard. Mater. 270: 102-109.

Gupta, A., K. R. Devendra, R. S. Pandey and S. Bechan. 2009. Analysis of some heavy metals in the riverine water, sediments and fish from river Ganges at Allahabad. Environ. Monitor. Assess. 157: 449-458.

Hatje, V., S. C. Apte, L. T. Hales and G. F. Birch. 2003. Dissolved trace metal distributions in Port Jackson estuary (Sydney Harbour). Australia Marine Poll. Bull. 46: 719-730.

Jordao, C. P., M. G. Pereira, C. R. Bellato, J. L. Pereira and A. T. Matos. 2002. Assessment of water systems for contaminants from domestic and industrial sewages. Environ. Monit. Assess. 79: $75-$ 100.

Mansour, S. A. and M. M. Sidky. 2002. Ecotoxicological studies: 3. Heavy metals contaminating water and fish from Fayoum Gov. Egypt Food Chem. 78: 15-22.

Mitamura, M., H. Masuda, T. Itai, T. Minowa, T. Maruoka, K. M. Ahmed, A. A. Seddique, D. K. Biswas, S. Nakaya, K. Uesugi and M. Kusakabe. 2008. Geological structure of an arsenic contaminated aquifer at Sonargaon, Bangladesh. J. Geol. 116: 288-302.

Neumann, R. B, A. P. St. Vincent, L. C. Roberts, A. B. M. Badruzzaman, M. A. Ali and C. F. Harvey. 2011. Rice field geochemistry and hydrology: an explanation for why groundwater irrigated fields in Bangladesh are net sinks of arsenic from groundwater. Environ. Sci. Tech. 45: 2072-2078.

Olawoyin, R., S. A. Oyewole and R. L. Grayson. 2012. Potential risk effect from elevated levels of soil heavy metals on human health in the Niger delta. Ecotoxicol. Environ. Saf. 85: 120-130.

OSHA. 1993. Occupational Safety and Health Administration. Occupational exposure to Cadmium; correction. United States Department of Labor, Federal Register. 58: 21778-21850.

Praveena, S. M., A. Ahmed, M. Radojevic, M. H. Abdullah and A. Z. Aris. 2007. Factor-cluster analysis and enrichment study of mangrove sediments-an example from Mengkabong, Sabah. Malaysian J. Anal. Sci. 11(2): 421-430.

Rahman, M. S. and M. R. Islam. 2010. Adsorption of Cd (II) ions from synthetic wastewater using Maple sawdust. Energy Sources, Part A (Recovery, Utilization and Environmental Effect). 32: 222- 
231.

Renner, R. 2004. Arsenic and lead leach out of popular fertilizer. Environ. Sci. Tech. 38: 382.

Savci, S. 2012. Investigation of Effect of Chemical Fertilizers on Environment. Procedia APCBEE., pp. 287-292.

Shamsuzzaman, M. M. and T. K. Biswas. 2012. Aqua chemicals in shrimp farm: A study from southwest coast of Bangladesh. Egyptian J. Aqua. Res. 38(4): 275-285.

Sheppard, S. C., C. A. Grant, M. I. Sheppard, R. de Jong and J. Long. 2009. Risk indicator for agricultural inputs of trace elements to Canadian soils. J. Environ. Qual. 38: 919-932.

Singh, M., G. Muller and I. B. Singh. 2002. Heavy metals in freshly deposited stream sediments of rivers associated with urbanization of the Ganga plain, India. Water Air Soil Poll. 141: 35-54.

Stellman, J. M. 1998. Encyclopaedia of Occupational Health and Safety: Chemical, industries and occupations. International Labour Organization (Electronic books). 63(44): 4230pp.

Tarras-Wahlberga, N. H., A. Flachier, S. N. Lanec and O. Sangforsd. 2001. Environmental impacts and metal exposure of aquatic ecosystems in rivers contaminated by small scale gold mining: the Puyango River basin, southern Ecuador. Sci. Total Environ. 278: 239-261.

USEPA. 1999. Appendix E: Toxicity Reference Values. Screening Level Ecological Risks Assessment Protocol for Hazardous Waste Combustion Facilities. Environmental Protection Agency, USA. Peer review draft, 3: EPA 530-D99-001C.

Wang, Y.M., P. Chen, R.N. Cui, W.T. Si, Y.M. Zhang and W.H. Ji. 2010. Heavy metal concentrations in water, sediment, and tissues of two fish species (Triplohysapappenheimi, Gobio hwanghensis) from the Lanzhou section of the Yellow river. China. Environ. Monitor. Assess. 165: 97-102.

Watson, C. and Roy P.E. Yanong 1989. Use of Copper in Freshwater Aquaculture and Farm Ponds. The Fisheries and Aquatic Sciences Department, UF/IFAS Extension. Reviewed August 2014 (http://edis.ifas.ufl.edu).

WHO. 2004. Guidelines for drinking water quality. World health organization, Geneva, Switzerland. 3(1): 8-15.

https://www.who.int/water_sanitation_health/dwq/GDWQ2004web.pdf 
